


\section{Fortællerens fødsel ud af snestormen}

\section{Om Johannes V. Jensens himmerlandshistorie »Kirstens sidste Rejse«}

\section{Af Anders Ehlers Dam}

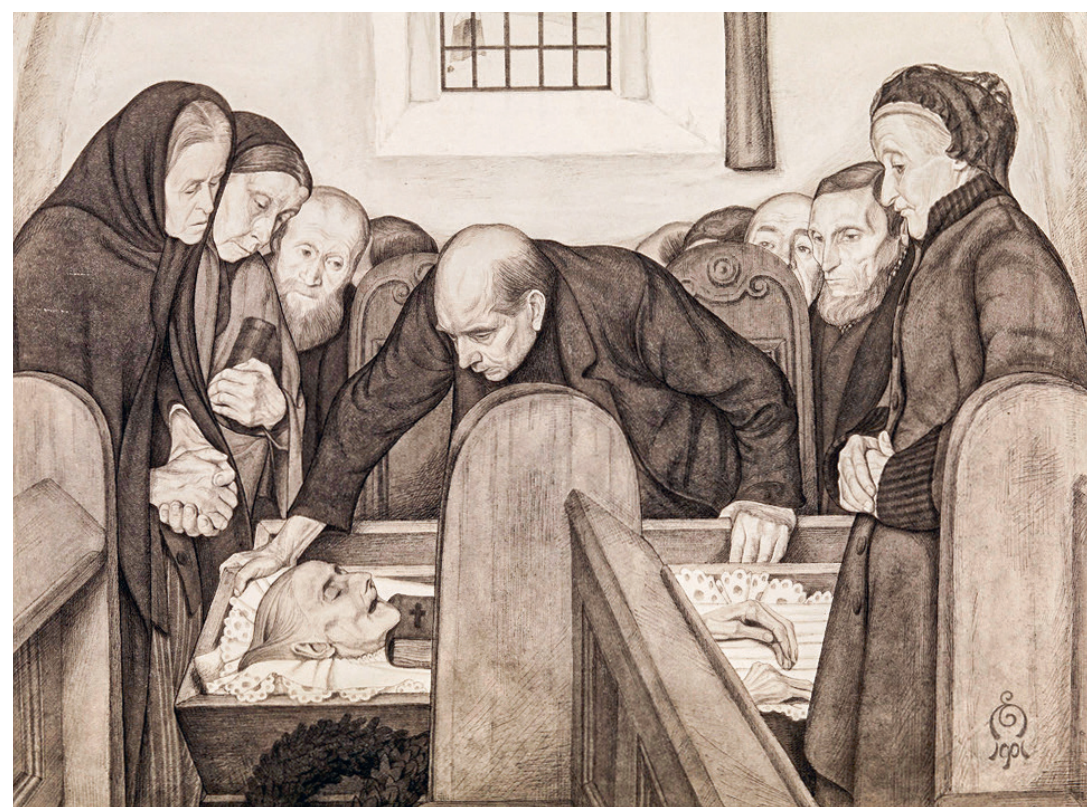

(C) Ejnar Nielsen/VISDA.

Ejnar Nielsen: Kirstens sidste Rejse. Pen, sort blcek, grå lavering. $335 \times 431 \mathrm{~mm}$. Statens Museum for Kunst. Brugt som illustration til Johannes V. Jensens »Kirstens sidste Rejse«, Julealbum, 1901.

In this article I analyze 'Kirstens sidste Rejse' [Kirsten's Last Journey], one of Johannes V. Jensen's stories from Himmerland, drawing on both the original version of the text published in 1901, and the version included in 1904 in Nye Himmerlandshistorier [New Stories from Himmerland]. At first sight, the story is realistic account of two men transporting a coffin with the corpse of an old woman from Aalborg to her home village in Himmerland where she is to be buried, and the violent snowstorm in which they are caught on the way. By the time they finally reach their destination, Christen Sørensen, who has been driving the horse-drawn carriage, has undergone a profound change. Earlier a silent person, he now recounts endlessly, with the same mechanical voice, the journey with the dead woman. In this article, I offer a reading of the story from the perspective of Maurice Blanchot's literary theory, arguing that Johannes V. Jensen's text can be read as an allegory of the becoming of the literary narration and its relation to the experience of death and nothingness. 
Johannes V. Jensens himmerlandshistorie »Kirstens sidste Rejse« blev første gang publiceret i 1901 i Julealbum, en af tidens populære årbøger. ${ }^{1}$ Knap tre år efter blev den - med nogle, som vi skal se, ikke uvigtige tilføjelser - genoptrykt i Nye Himmerlandshistorier (1904). Fortællingen var i den oprindelige version suppleret med en pennetegning lavet til lejligheden af den symbolistiske kunstner Ejnar Nielsen. På illustrationen ses en af fortællingens sidste scener, hvor Christen Sørensen omgivet af andre himmerlandsbønder tager en sidste afsked med sin afdøde faster, Kirsten Smed, som er død på en anstalt i Aalborg efter at have mistet forstanden. Forinden har Christen sammen med en karl fragtet kisten med afdøde de otte mil fra Aalborg til Graabølle, for at hun kan blive jordfæstet ved siden af sin familie i hjembyen. Normalt ville de have kunnet være tilbage igen dagen efter, at de drager afsted om tirsdagen. Imidlertid sætter et forfærdeligt snevejr ind samme aften, og først om lørdagen vender de, stærkt medtagne af den strabadserende tur, tilbage, og begravelsen kan endelig finde sted.

Ansigterne på tegningens personer er andægtige, og alle stirrer mod den tynde og udmarvede Kirsten, hvis tandløse mund står åben i en sort sprække. Et klæde er lagt om hendes lille indskrumpede krop, og med Bibelen skudt helt op mod hagen ser det - havde det ikke været for de knoklede hænder - næsten ud, som om hovedet lå der for sig selv. Mens de øvrige folk står tilbageholdende i kreds om kisten, bøjer Christen sig, med begge hænder støttet mod kisten, ned mod liget, og man får indtryk af, at der er en særlig kontakt mellem ham og ligets lukkede, udslukte øjne. Lige over Christens hoved kan man ud ad kirkens gitterrude se det tilsneede landskab udenfor, hvor en gravsten står klar til Kirstens nye opholdssted. Sneen ligger der som et visuelt ekko af den store hvidhed, som Christens rejse med den døde passerede igennem - en rejse gennem det inderste af snestormen, et snelysende tusmørke, hvoraf fortællingen om Kirstens sidste rejse er blevet til.

Ligesom Christen bogstavligt talt befinder sig i midten af Ejnar Nielsens tegning, er det også hans karakter, det skal dreje sig om i denne læsning af Johannes V. Jensens fortælling. Spændt ud mellem dødens nærhed og sneens hvide intethed - ligesom på tegningen - er det nemlig ham, der

$1 »$ Kirstens sidste Rejse« citeres efter: Johannes V. Jensen: Himmerlandshistorier. Bd. 1. Udg. af Per Dahl og Aage Jørgensen. Danske Klassikere. Det Danske Sprog- og Litteraturselskab. København 2018, s. 251-260. Der er tale om den version af teksten, som indgik i Nye Himmerlandshistorier (1904), men der redegøres for tilføjelserne i forhold til versionen i Julealbum på s. 279. 
udgør det egentlige centrum i denne tekst, der tæller som en af Jensens mest kendte himmerlandshistorier.

Hvad er det for en erfaring, Christen har gjort på rejsen med kisten gennem snestormen i de tre døgn? Og hvori består den tranformation, han gennemgår på turen? Før han tog afsted, var han en tavs mand, der helst ikke talte. Men bagefter kan han slet ikke holde op igen. Hvordan skal man forstå den underlige, upersonlige stemme, der lyder, når han fortæller? Det er disse spørgsmål, jeg tager op. Det skal altså hverken handle om vigtige nok tekstelementer som karakteren Kirsten - som jo immervæk figurerer i titlen - eller det specifikt himmerlandske ved fortællingen. Man kunne selvsagt også med god ret vælge at læse teksten som en realistisk fortælling med et psykologisk tema. Men jeg spørger her i stedet til et underligt centrum i teksten, som det er vanskeligt ikke at læse i poetologisk retning: Historien om Christens tilblivelse som fortæller kan således forstås som en allegori over grundlæggende forhold i visse litterære tekster. Jeg koncentrer mig først om snestormen og dens funktion i fortællingen; dernæst ser jeg på, hvordan denne tavse mand i snestormen bliver til en fortæller, og på, hvad der karakteriserer den stemme, han har som fortæller; endelig relaterer jeg min forståelse af teksten til Maurice Blanchots teori om den litterære tekst, før jeg afslutningsvis sammenligner de to versioner af fortællingen.

\section{Snestormen}

Snestormen, der indtræffer i »Kirstens sidste Rejse«, er i min læsning ikke kun en almindelig voldsom snestorm i en realistisk fortælling, men fremstår som en hændelse med symbolske træk. Det er, som vi skal se, en ekstrem og grænseoverskridende begivenhed, hvor orienteringspunkterne i tid og rum ophæves, og den repræsenterer en erfaring af intethed og forskelsløshed, hvoraf en fortælling bliver til.

Om snestormen hedder det: »Det var en Tredages-Snefog, der satte ind, den kom med bidende Kulde, Brandstorm og Sne, saa Himmel og Jord stod i een Taage« (251). Sneen ligger i »mandshøje Driver«, og »Stormen gik strid og iskold, Alverden var i en pibende Fog « (251). Snestormen har betydning både for folkene $\mathrm{i}$ landsbyen og for Christen på hans og karlens rejse med den døde. Hjemme i landsbyen, hvor man utålmodigt og bekymret venter på kisten med Kirsten, har snestormen en karnevalistisk effekt, hvor hverdagen sættes ud af kraft. Jensen arbejdede med lignende karnevalistiske effekter i andre af sine tekster, for eksempel »Syvsoverne«, 
der også stod i Nye Himmerlandshistorier, hvor ruderne dækkes til, sådan at familien tror, at det bliver ved med at være nat, selvom det faktisk er blevet dag, og »Wombwell« om det fantastiske menageri, der sætter egnen på den anden ende, fra samme værk. I »Kirstens sidste Rejse« er snestormen skildret som en undtagelsessituation, hvor der vendes op og ned på tingene, og hvor det menneskelige formindskes og relativeres: »Kulden gjorde alle Mændene saa smaa« (252). Landskabet forvandles i snestormen. Naturens farver dækkes og udviskes af snedrivernes hvidhed, og formerne blødes ud eller forandres i snedrivernes nye formationer. Paul G. Lange har peget på metamorfosens betydning i fortællingen:

I skildringen af landskabsbilledet er der lagt tydelig vægt på en totalforandring fra det blide, hverdagskendte, hvor tingene har deres faste pladser, hvor landskabets konturer er intakte, og hvor mennesket indgår som et naturligt led med sine »tilvante « dimensioner, til det fremmede, næsten ødelagte, konturløse og overdimensionerede, der tvinger mennesket i knæ, gør det til »en sort Myre« $\mathrm{i} » d e$ blændende Ørkener.« (Lange 1968: 118f.)

For Christen og karlen ude i det vejløse uvejr kommer snestormen til at repræsentere overskridelsen af en grænse ind i en symbolsk, tidløs region, hvor døden er nærværende.

Undervejs i fortællingen ligger synsvinklen hele tiden i landsbyen. Som læser er man på intet tidspunkt med ude på køreturen. Hvad vi ved om rejsen i snestormen med den døde Kirsten, har vi udelukkende fra Christen, sådan som han fortæller det, da han er kommet tilbage. Disse forskydninger mellem fabula og sjuzet gør, at vi som læsere i første del af fortællingen, ligesom landbyboerne, ikke ved, hvordan det skal gå med dem på turen gennem stormen. Onsdag og torsdag dukker Christen således ikke op, og folkene i byen frygter, at en ulykke kan være sket. Christen, som selv er undervejs til at blive en fortæller, fostrer også i sit fravær fortællinger. »I de tre Døgn, Christen Sørensen havde været ventet, var han bleven en Sagnskikkelse« (254). Og om fredagen bliver uvejret endnu værre:

Om Fredagen blev Vejret saa haardt, at Ingen havde kendt Mage. Det var en Orkan, og Luften var saa fuld af Sne, at Dagen ikke kunde trænge igennem Skyen. Folk sad i Tusmørke inde i Stuerne. (...) I det Par Dage brast alt Samkvem, man kan sige, at al Kultur ophørte. (253) 
Det er en situation, hvor den normale menneskelige orden og »al Kultur« er nedbrudt. Verden er ude af sig selv. Mens stormen står på, kan dagen ikke trænge igennem, men er erstattet af et »Tusmørke«, hvor sneen på samme tid lukker lyset ude og lyser op med sin hvidhed. Om lørdagen er det mere roligt vejr, og alt er forandret og uigenkendeligt: folkene $» k e n d t e$ knap deres By og Egn igen«: »Selve Egnen var ukendelig, de Høje og Agerrundinger, man var vant til at se, havde Sneen jævnet og paa andre Steder havde der dannet sig ukendte Fremspring i Terrænet. Synskredsen var en anden.« (254).

Alle i landsbyens lille samfund er i tankerne beskæftiget med, hvordan det går med Christen og karlen og kisten med Kirsten. Det er en uvished og venten, man deler som læser. Så erfarer man endelig, at ligtoget er på vej og er en mil fra byen. Foran går en gruppe af snekastere, og fra landsbyens side graver andre snekastere sig vej. »Forventningen om Indtoget antog overnaturlige, uklare Former« (255). Til sidst mødes snekasterne, og Christen kan køre igennem. Først nu hører vi i fortællingen om ham. Der indtræder en vending i teksten, idet det, vi nu erfarer, er, hvad Christen beretter om de forgangne dages hændelser.

Hvad har Christen og karlen da oplevet på denne rejse til fimbulvinterens hjerte? Christen var ikke nogen fortæller før ottemilsrejsen, men han er blevet forvandlet til en fortæller af den. Ud af snestormen blev fortælleren og fortællingen til. »Folk dannede sig en Forestilling om Rejsen af de to haardt medtagne Menneskers Fortælling« (256). Det samme gælder for læseren, for først nu hører man, som i en fortælling i fortællingen, om hændelserne.

Christen fortæller, at de måtte køre fra kro til kro, og undervejs har de også måttet skifte vogn, fordi deres egen gik i stykker. På turen er de tyet til brændevinsdunken for at holde sig i live, og derfor er de endnu halvberusede og også på den måde ikke sig selv.

Om rejsen gennem snestormen hedder det:

De fo'r vild, de tabte al Orientering, vidste tilsidst hverken Rede paa Sted eller Tid. (...) [M] eget af Vejen kune de slet ikke huske; der havde de rejst som rene Søvngængere. Om Torsdagen var de nær omkommen, da der ingen Folk var ude, og de kørte fast midt ude paa de vilde Agre. (256f.)

Det tætte snefog beskrives som et rum, hvor ordnende referencepunkter er forsvundet. De kan ikke orientere sig og mister tidsfornemmelsen. Det 
er et forskelsløst rum, hvori man bevæger sig som søvngængere. Karlen falder i søvn undervejs, men for Christen er det én lang snehvid søvnløshed. De er nær ved at miste livet, hører vi. I snestormen bevæger de sig i et område mellem liv og død og mellem vågenhed og søvn.

\section{Fortælleren}

Ligesom en tekst bliver til i det hvide landskab, som siden og dens intethed udgør, forvandles Christen i snestormen fra at være bærer af indesluttet tavshed til at være den egentlige fortæller af historien om Kirstens sidste rejse. Den lydlige lighed mellem »Kirsten«, »Kisten« og »Christen« er næppe tilfældig. Kun Christen selv har erfaret det uigennemtrængelige susende tusmørke mellem liv og død, et intethedsrige, som han berøvet søvnen har gennemrejst med den døde kvinde bag sig i de tre døgn. Han dør ikke selv i snestormen, selvom han er i livsfare, men han har - i bogstavelig forstand - været konfronteret med døden. Han fortæller således sine forundrede lyttende medborgere fra landsbyen, at kisten i snestormen var røget af hestevognen, og låget var gået af den, sådan at den døde var trillet ud i sneen. Som bruddet på et tabu, som en grotesk åbenbaring, blev låget helt konkret løftet for noget, man ikke burde se på den måde og på det tidspunkt. Midt i snestormen blev låget løftet for døden. Konfrontationen med den døde midt i det hvide ingenmandsland, synet af den døde, uden ligets rolige fred, som når det ligger til skue i kirken (som på Ejnar Nielsens tegning), men i forkerte rammer, væltet ud af kisten og ramlet ned i sneen, får ham efter turen til at tale og fortælle.

Der er noget orfisk ved hændelsesforløbet. Det er ikke en egentlig genskrivning af orfeusmyten, men der er ekkoer af det orfiske i situationen med rejsen med den døde bag sig gennem det fremmedartede hvide snemørke, på vej med Kirsten fra døden på galeanstalten tilbage i retning af det hjemlige og begravelsens afslutning og hvile. »To be human means above all to bury«, skriver Robert P. Harrison (2003: xi). På den kaotiske, langstrakte rejse, hvor Kirsten ingen fred endnu har fundet, revner tilværelsen ind til en ikkemenneskelig, søvnløs zone, hvor alle ordnende forskelle er visket ud. I den ekstreme situation vender Christen sig mod den døde bagved og ser hende og rører ved hende, for det stive kolde ligs næse blev brækket, da kisten faldt af vognen.

Det er denne rejse med den døde kvinde gennem snestormen, hvor han berører den døde, og hvor han mærkes af dødens nærvær, der gør, at han 
bliver til en fortæller. I mellemriget mellem liv og død, mellem hvileløshed og hvile, vender han sig og ser den døde. Hans fortælling opstår og forsvinder på en måde i samme øjeblik: Han kan herefter fortælle om noget, der ellers ikke kan fortælles om, give stemme til noget normalt usigeligt, og dette sker, derved at dødserfaringen og snerigets forskelsløshed bevares i hans stemme som en tavshed, der er vævet ind i det talende, en neutralitet, der gennemtrænger den fortællendes stemme.

\section{Stemmen}

Lad os se nærmere på Christen, som han fremstår efter tilbagekomsten. Hvad er det for en mand, der vender hjem? Vi hører, at han for de andre i landsbyen er fuldstændig forandret efter sine erfaringer. Det kommer til udtryk i selve det, at han fortæller, og i hans måde at tale på.

Men Folk kendte ikke Christen Sørensen igen. Han var opsvulmet i Hovedet og havde faaet en hel anden Stemme. Han var bleven snakkesalig; mens han stod og bankede sine Hænder og sank i Knæene, snakkede han uafbrudt. Han henvendte sig ikke til nogen bestemt, og han var rent aandsfraværende. (...) Der blev saa uhyggelig stille om ham. Han stod og snakkede i et væk som en Maskine, uden Spor af Sindsbevægelse; alle maatte se paa det sprængrøde Ansigt med de halvbrustne Øjne. Han havde stillet sig ved Forhjulet af Vognen og klemte paa, for at de kunde faa det at vide altsammen, han vilde føje dem, skønt han var udslidt af Søvnløshed og Drik og fordummet af Kulde. Han holdt paa Tømmen med hovne og magtesløse Fingre .... og allerbedst som han stod, glippede han langt og mødigt, Mælet sank ned til en dæmpet Sludren, han nikkede, stod og smaasov. (255f.)

Christen kan ikke lade være med at snakke, selvom han er udkørt, men hans mumlende og sludrende og neutrale måde at tale på virker fremmedartet og uhyggelig for tilhørerne. Han taler ud i luften, hans henvendelse er »ikke til nogen bestemt«, men har løsrevet sig fra det hverdagskommunikative område. Han har nu »en hel anden Stemme«. Da der kommer nye folk til, »hævede han Stemmen og fortalte forfra om den lange, lange Rejse« (256). Han vil fortælle, men fortæller repetitivt, monotont og maskinagtigt. 
At hans henvendelse har løsrevet sig fra en normal kommunikativ situation, viser sig atter engang, da de kommer til kirken. Heller ikke her synes han at have nogen tanke om modtagere af hans uafbrudte tale, og han taler også uden sans for den kontekst, han taler i: »Medens alle de andre i Kirken hviskede eller tav, blev han ved at tale højt og lige ud som paa ethvert andet profant Sted « (257). I hans stemme er »al Kultur ophørt«, for at bruge udtrykket om snestormen. Efter erfaringen af den store neutralitet i snestormen profanerer han med sin måde at tale på det hellige og det socialt konventionelle og tager ingen hensyn til forskelle. Ikke for at provokere, men fordi det forskelsløse har blandet sig med hans stemme og stemmeføring. Igen er han profan, da han, den fortrolige med døden, spørger de andre, om de vil se liget. Mekanisk sludrende viser han dem den døde frem - sådan som det er afbildet på Ejnar Nielsens tegning - og rækker endda profant ud og retter på den brækkede næse: Han »løftede Laaget af Kisten, stadig under en Strøm af meget jævne Ytringer« (258).

Den forandrede Christen taler således konstant, og hans stemme er mekanisk og uden personlighed. Han er på en måde ikke længere et normalt $» j$ eg«. Han plaprer løs og har hverken magt over ordet eller stemmen. Hans sædvanlige stemme er brudt og uhyggeliggjort af rejsen i sneens ingenmandsland, og død og neutralitet taler nu med i den.

Christens stemme er også en stemme, der, berøvet stemmens normale karakteristika, ikke rigtigt kan gengives af forfatteren. Den er uden nærvær og fremstilles først og fremmest indirekte og dækket, i og med at den alvidende fortæller beskriver den. De gange Christen er repræsenteret gennem citat eller replik, er det ved ret korte udsagn, der ikke vidner om stemmen. Det er de fremstillede personer, der finder Christens stemme underlig - kun indirekte læseren via beskrivelserne af den.

Stefan Iversen, der i Den uhyggelige fortcelling beskæftiger sig med tekster af Johannes V. Jensen, hvor der er usikkerhed om stemmen, peger på, at ikke kun det tematiske niveau, men også spørgsmål vedrørende tekstens udsigelsesstatus er af relevans i analysen af det, han betegner som »uhyggelige fortællinger« hos Jensen: »Den ofte omtalte negativitet hos den tidlige Jensen (gru, nihilisme, tomhed, fravær) angår ikke kun tematiske forhold, men skyldes også selve teksternes strukturer, deres udsigelses udspring og forankring « (Iversen 2018: 11). Iversen »reserverer betegnelsen til at gælde fortællinger, der både tematiserer og producerer stemmetvivl, det vil sige både skildrer intentionalitetsproblematikker i det fremstillede univers og fremtvinger dem hos læseren i kraft af fremstillingen.« (Iversen 2018: 129) »Kirstens sidste Rejse« er til dels en uhyg- 
gelig fortælling, i og med at det neutrale og uhyggelige har blandet sig med Christens stemme og fremmedgjort den for de andre i landsbyen. Der er tale om, hvad Iversen kalder dialogisk tvivl, dvs. »stemmetvivl«, der fremkommer, når stemmer i fortællingen »opstår i forbindelse med det endnu-ikke-helt eller det ikke-længere-helt menneskelige samt i tilfælde, hvor mennesker udtrykker sig mekanisk, eller mekanik udtrykker sig menneskeligt« (Iversen 2018: 15). Jensens fremstilling heraf afstedkommer også en effekt i tekstens læser af noget fremmedartet, vil jeg mene, men selve tekstens forankring af udsigelsen er ikke det afgørende, og på den måde er der ikke tale om en uhyggelig fortælling i Iversens forstand. Og dog: Det faktum, at Christens stemme primært fremtræder i dækket form, er måske ikke i sig selv »uhyggeligt«, men det bidrager ikke desto mindre til en mystificering af denne underlige, ikke-kommunikative stemme, der er tømt for liv og nærvær, hos læseren. ${ }^{2}$

»Kirstens sidste Rejse« ender med, at Christens formløse og bortvendte tale endelig bliver bragt til ophør: „Christen forstummede ikke, før Præsten kom. Det havde været pinligt for Folk at høre paa ham. Christen Sørensen var til daglig en Mand, der holdt paa Formerne (...) han havde aldrig før snakket saadan op i en Forsamling« (259). Før Kirsten bliver lagt i jorden, fører en person Christen bort, og han »lod sig viljeløst lede« $(260)$.

Da de var kommen et Stykke ned ad Vejen, begyndte Benene at slaa Sludder under Christen Sørensen, Anders Nielsen maatte saa godt som bære ham. Christen Sørensen snakkede i Vildelse, mens han gik, han svælgede og kæmpede imod Søvnen. Da de kom til hans Gaard, hang han som en død Vægt paa Anders Nielsens Arm, men endda blev Benene ved at flytte sig under ham. Han kendte sin Port, da de gik ind i den, gav en sagte Klagelyd og sank sovende om for Anders Nielsens Fødder.

2 Jeg har konsulteret diverse andre narratologiske teorier for at se, om de kunne belyse de aspekter ved Jensens tekst, som jeg interesserer mig for, men synes ikke, jeg har fundet noget af relevans. Min interesse ligger således et andet sted end narratologiske diskussioner af stemmebegrebet i forlængelse af Gérard Genette, fx: Andreas Blödorn, Daniela Langer og Michael Scheffel (red.): Stimme(n) im Text. Narartologische Positionsbestimmungen. Berlin/New York 2006, og: Per Krogh Hansen o.a. (red.): Strange Voices in Narrative Fiction. Berlin/Boston 2011. Ej heller såkaldt unaturlig narratologi har jeg fundet det relevant at inddrage i denne sammenhæng, jf.: Jan Alber, Stefan Iversen, Henrik Skov Nielsen og Brian Richardson: »Unaturlige fortællinger, unaturlig narratologi: Hinsides mimetiske modeller«, i: $K \& K-$ Kultur \& Klasse, årg. 11, nr. 112, 2011, s. 7-32. 
Hans Træk jævnedes øjeblikkeligt, det kom saa dulmende over ham. (260)

Som fortællende befandt Christen sig i et område mellem vågen og sovende, bevidst og ubevidst, ja, det kan ligefrem lyde som om, at det er tilstanden mellem liv og død fra rejsen, der er forlænget ind i hans måde at fortælle på. Han synker endelig sammen og forsvinder i søvnens rige, da han er hjemme, men denne søvn minder om døden. Han er »som en død Vægt«, og som hos en død slappes ansigtet og dets træk. Vigtigst er det dog, at Christens kollaps også medfører afbrydelsen af hans fortællen, og at også Jensens tekst holder inde i samme øjeblik. Strømmene i henholdsvis Christens og Jensens fortællinger løber sammen og finder et fælles udløb i den intethed, der findes i selve tekstens ophør.

\section{Det neutrale}

Der er, som allerede antydet, noget poetologisk over dette, at Christen gennem sine erfaringer i ridtet gennem snestormen forvandles til en fortæller, og at disse erfaringer mærker hans fortællende stemme med en mærkelig neutralitet. At se »Kirstens sidste Rejse« som en tekst blot om Himmerland og dets befolkning og den i perioden forsvindende gammelkultur ville bestemt være reduktivt, for den åbner perspektiver, der rækker frem mod avancerede teorier om litteraturens væsen i det 20 . århundredes modernisme. Hvis man sammenholder Jensens tekst med Maurice Blanchots litteraturteori, er der eksempelvis en række fællestræk mellem den franske tænkers opfattelse af litterær erfaring og de indlejrede forestillinger, vi har læst ud af Jensens fortælling. ${ }^{3}$

I litteraturen som kunst erfarer man, ifølge Blanchot, netop en neutralitet og et fravær, som altid findes som en skyggeside af ordenes benævnelse af tingene, men som man ikke bemærker i hverdagssprogets kommunikative sprogbrug. Og det er netop »det neutrale«, som Orfeus

3 Det er ikke første gang, Johannes V. Jensen sammenføres med Maurice Blanchot. Stefan Iversen leverer således en blanchotsk læsning af himmerlandshistorien »Oktobernat« (1897) i »Alt er undergivet Forvandling. Om Himmerland i Johannes V. Jensens forfatterskab « i: Passage. Tidsskrift for litteratur og kritik, nr. 54, 2005, s. 45-54. Iversen ser fortællingen som tematiserende en »radikal negativitetserfaring«, hvor mørket og den susende vind ophæver forskellene: »Det, der før var ord, baseret på sprogets systemer af forskelle, annulleres i mørket, der gør alt lige gyldigt« (s. 47). 
erfarer i Blanchots digterfilosofiske genskrivning af myten om Orfeus og Eurydike i L'espace littéraire (1955). Blanchot opfatter Orfeus som digteren, der oplever, at natten i sit inderste afslører en anden nat, der ikke indgår i et modsætningsforhold til dagen, men som opsuger forskellene i sig. Hvad digteren søger i sin inspiration, er »at se det i natten som natten skjuler, den anden nat, skjultheden der kommer til syne « (Blanchot 1994: 108). Horace Engdahl har opsummeret Blanchots ideer således:

Den verklighet Blanchot söker i litteraturen är inte fortsättningen av den kända världen utan det andra, det som undgår motsatsernas spel: en bortvänd och avgrundslik sida av altet. Hans mest älskade namn för denna dunkla zon, i vilken vår existens likväl är nedsänkt, är 'natten' och 'det neutrala', ord som han mot bättre vetande skulle vilja ge en etymologisk släktskap (nuit-neutre). Det är en sömnlöshetens natt utan stjärnor och utan gryning; ett neutrum utanför tiden, något som börjar om för evigt överallt, lever och dör utan slut, utan individuella avtryck. (Engdahl 1992: 128)

Fuldstændig lighed mellem forestillingerne hos Jensen og Blanchot er der naturligvis ikke, men Jensen berører i sin fortælling fra 1900-tallets begyndelse i digterisk form nogle af de ideer, der udvikles i detaljer hos den franske litteraturteoretiker, der tæller blandt de vigtigste i det 20. århundrede. Også Christen har således på sin orfiske rejse med den døde erfaret, at tilværelsen blottede en fundamental neutralitet i tusmørket mellem liv og død. Og da han efterfølgende fortæller, er neutraliteten bevaret $i$ hans stemme, der er udhulet for det menneskelige og lyder maskinagtig.

»Fortællekunst sætter det neutrale i spil« skriver Blanchot i sin tekst om »Den narrative stemme« i L'entretien infini (1969) (Blanchot 1994: 179). Det anonyme, neutrale område, litteraturens sprog fører ind i, overskrider subjekt, identitet, mening og individuel intention. Konkret ved at den litterære tekst overskrider den biografiske forfatter og får et liv, der kan vare ved, efter ophavsmanden måtte være forsvundet fra Jordens overflade. Det litterære sprog er for Blanchot ikke et sprog, som der kommunikeres med mellem en afsender og en modtager, men er selvgyldigt. I den litterære tekst, skriver Blanchot, markerer overgangen fra $» j$ eg « til »han« (»je« til »ilk) det neutrale i en fortælling. Christens fortælling fungerer som en allegori over et sådant litterært sprog, hvor det neutrale sættes i spil. Hans »jeg« er, da han fortæller, afsubjektiveret og upersonligt, og i den forstand er hans »jeg« blevet til et anonymt »han«. 


\section{To versioner}

»Litteraturens ideal«, skrev Blanchot allerede i den programmatiske artikel »Litteraturen og retten til døden« i La part du feu (1949), er »at sige intet, talen for intet at sige « (Blanchot 1994: 54). Christen siger intet, når han plaprer maskinagtigt, han udtaler den intethed, han har erfaret i snestormen, og Jensens tekst handler om dette intet. Det er det på samme tid dunkle og hvide sneunivers i fortællingen og undtagelsestilstanden til sammen med beskrivelsen af Christens neutrale stemme, der fascinerer læseren.

Jeg ser således i min læsning, som sagt, karakteren Christen som den centrale instans i fortællingen og ikke Kirsten, om end Christen som fortæller netop, som på Ejnar Nielsens tegning, står i en særlig kontakt med den døde. Fornemmelsen af, at også Jensen selv initialt var mere fascineret af Christen-figuren end af Kirsten underbygges af en sammenligning af førsteudgaven af »Kirstens sidste Rejse«, sådan som den stod trykt $\mathrm{i}$ Julealbum i 1901, og den senere version i Nye Himmerlandshistorier tre år senere, hvor Jensen havde tilføjet tre lange - i sekundærlitteraturen ofte citerede - afsnit til slut, der netop handler om Kirsten.

I den oprindelige version hører vi næsten intet om Kirsten. I anden version derimod er der tilføjet halvvejs sentimentale passager, der trækker fortællingen bort fra fortælleren Christen og hans mekanisk-neutrale stemme og det poetologisk-allegoriske i retning af hyldesten til den afdøde, det anekdotiske og hjemstavnsskildringen. Tilføjelserne gør det mere nærliggende at placere også denne fortælling som del af det folkelige gennembrud, sådan som det ofte gøres med himmerlandshistorierne i receptionen. ${ }^{4}$ For eksempel hedder det $\mathrm{i}$ den senere udgave af fortællingen:

4 Det er ofte med god grund, at en stor del af receptionen af Jensens himmerlandshistorier knytter an til denne opfattelse af, at den forsvindende bondekultur og det himmerlandske landskab er det centrale i disse tekster. Synspunktet formuleres smukt af Martin A. Hansen: »Digteren ved, at det er en vigende Verden, han fortæller om. En Undergang. Almuekulturen er næsten død da han begynder. Den er ved at udaande. Gennem hele forrige Aarhundrede sygner Bondefolkets gamle Levemaade hen, Vaner og Skikke, dens særlige Aand, der næsten ikke havde ændret sig siden Middelalderen. Men i sin Undergang blomstrer den. Et Træ der skal gaa ud, det er bugnende fuldt af Frugt i sin sidste Høst. I sin Bortgang slynger denne gamle Kultur pludselig, som i et Stormkast, en Skare Fugle, et Kor af Fortællere og Sangere ind i vor Digtning.« Martin A. Hansen: »Himmerlandshistorierne«, radioforedrag fra 9. oktober 1949, her citeret efter: Martin A. Hansen (1965: 108-115). 
Al den mageløse Varme, der havde lyst ud af Kirstens furede Ansigt, den var nu kun et fattigt Genskin i deres Øjne, der huskede hende; de Skatte af Ydmyghed og af Prøvelser og af Visdom i menneskelige Ting, der laa gemt i Kirstens dybe Hjærte, de var nu svage Billeder i de Efterlevendes Erindring. (259)

Det er her den himmerlandske verden, som forsvinder i og med Kirsten og andre lignende figurer, som det handler om.

Kirsten var nu hos de Trofaste, de gamle Bondeskikkelser, der aldrig skal rejse sig mere, de gamle milde Folk, der har bedt sig undskyldt, og som ikke lod andet Eftermæle efter sig paa deres Kors af Træ, end at de var fødte og døde i Graabølle. (259)

I de tilføjede passager drejer Jensen sin tekst i retning af den himmerlandske bondeskikkelses »Eftermæle«. Men i den oprindelige version er det Christens orfiske rejse gennem snestormen, mellem liv og død, og hans fødsel som fortæller, der fremstår som det egentlige fascinationspunkt: teksten ikke som et eftermæle, men et profant-mekanisk fortællende mæles opståen ud af erfaringen af død og forskelsløshed i sneen, stadig med spor af intethed og neutralitet i sig, fortællerens fødsel ud af snestormen.

\section{Litteratur}

Blanchot, Maurice: Orfeus' blik og andre essays. Oversat af Carsten Madsen. København 1994.

Engdahl, Horace: »Efterskrift«, i: Maurice Blanchot: Essäer. Udg. af Horace Engdahl. Lund 1992, s. 125-139.

Hansen, Martin A.: »Himmerlandshistorierne«, i: Ved Korsvejen. Littercere Essays. Udg. af Thorkild Bjørnvig og Ole Wivel. København 1965, s. 108-115.

Harrison, Robert Pogue: The Dominion of the Dead. Chicago/London 2003.

Iversen, Stefan: »Alt er undergivet Forvandling. Om Himmerland i Johannes V. Jensens forfatterskab«, i: Passage. Tidsskrift for litteratur og kritik, nr. 54, 2005, s. 45-54.

Iversen, Stefan: Den uhyggelige fortcelling. Unaturlig narratologi og Johannes $V$. Jensens tidlige forfatterskab. Aarhus 2018.

Jensen, Johannes V.: »Kirstens sidste Rejse«, i: Johannes V. Jensen: Himmerlandshistorier. Bd. 1. Udg. af Per Dahl og Aage Jørgensen. Danske Klassikere. Det Danske Sprog- og Litteraturselskab. København 2018, s. 251-260. 
$176 \cdot$ Anders Ehlers Dam

Lange, Paul G.: »Kirstens sidste rejse«, i: Meddelelser fra Dansklcererforeningen, nr. 2, 1968, s. 118-122. 